\title{
Seasonal cycling of mercury and monomethyl mercury in the Venice Lagoon (Italy)
}

\author{
Nicolas S. Bloom ${ }^{\mathrm{a}, *}$, Ligia M. Moretto ${ }^{\mathrm{b}}$, Paolo Scopece $^{\mathrm{b}}$, Paolo Ugo ${ }^{\mathrm{b}}$ \\ ${ }^{a}$ Studio Geochimica, 8057 Corliss Ave. N., Seattle, WA 98103, USA \\ ${ }^{\mathrm{b}}$ Dipartimento di Chimica Fisica Universita Ca'Foscari di Venezia, S. Marta, 2137 Venezia 30123, Italy
}

Received 17 October 2003; received in revised form 21 May 2004; accepted 10 June 2004

Available online 21 August 2004

\begin{abstract}
From 1950s to 1980s, the Venice Lagoon was extensively contaminated with mercury (Hg) from chlor-alkali discharges and other sources, prompting researchers to assess the distribution of contamination in sediments and biota. Since the lagoon is shallow and bordered by extensive wetlands, contains high sulfate from the sea, and high nutrient loading from agricultural runoff and urban sewage, it is expected to act as a vigorous microbiological incubator for Hg methylation. Here we report seasonal findings (2001-2003) for total $\mathrm{Hg}$ and monomethyl mercury $\left(\mathrm{CH}_{3} \mathrm{Hg}\right)$ in water column, rivers, precipitation, suspended matter, sediments, and biota samples collected using ultra-clean sampling techniques. Aqueous total $\mathrm{Hg}$ ranged from about 5-10 pM at the Lido entrance to the Adriatic, to 25-100 pM within the main body of the northern lagoon. A sudden drop in $\mathrm{Hg}$ concentration is observed when crossing the Canale dei Petroli,the major deep-water shipping canal which roughly bisects the lagoon) in a southward direction. The less contaminated southern reaches of the lagoon were not studied as intensively, but were found to contain only $10-20 \mathrm{pM}$ total $\mathrm{Hg}$. Up to $250-1000 \mathrm{pM}$ were observed in the industrially impacted areas and urban canals. Most $\mathrm{Hg}$ was from re-suspended sediments, as levels are strongly correlated with total suspended solids (TSS) in this very shallow $(<1 \mathrm{~m})$ lagoon. Dissolved $\mathrm{Hg}$ concentrations were narrowly constrained to the range of approximately 3-15 pM. Monomethyl mercury ranged from about $0.1-2 \mathrm{pM}$ in unfiltered samples and $0.03-1 \mathrm{pM}$ in the dissolved phase. Surface $(0-3 \mathrm{~cm})$ sediments varied from about $2.5-12.5 \mathrm{nmol} \mathrm{g}^{-1}$, with $0.1-0.3 \%$ of that as $\mathrm{CH}_{3} \mathrm{Hg}$. Monomethyl mercury levels were about three times higher during the spring and summer, compared to winter. The lagoon appears to be moderately, but extensively contaminated by $\mathrm{Hg}$, showing concentrations of both total $\mathrm{Hg}$ and $\mathrm{CH}_{3} \mathrm{Hg}$ similar to those reported in other urban harbors, but spread over hundreds of $\mathrm{km}^{2}$. The impact of the historic direct chlor-alkali discharges to the lagoon is diffused throughout the system by an array of re-suspension pathways, but may ultimately be mitigated by rapid tidal flushing.
\end{abstract}

(C) 2004 Elsevier B.V. All rights reserved.

Keywords: Venice lagoon; Mercury; Monomethyl mercury; Chemical speciation; Seasonal variations

* Corresponding author.

E-mail address: nicolasb@nickslab.org (N.S. Bloom). 


\section{Introduction}

Venice and its lagoon are simultaneously one of the cultural wonders of the world and a sensitive coastal marine habitat under growing stress due to centuries of anthropogenic pollution and continuous terraforming. The lagoon (Fig. 1) encompasses approximately $540 \mathrm{~km}^{2}$, of which $62 \%$ is open water, $13 \%$ are salt marshes, $17 \%$ diked fish farms, and $8 \%$ islands (Pellizzato, 1996). The average depth of the entire lagoon is only $1.1 \mathrm{~m}$ and owing to a tidal cycle that often exceeds $1 \mathrm{~m}$, huge areas are alternately submerged and then emerged daily. In such ecosystems, the $\mathrm{Hg}$ cycle is dominated by direct coupling

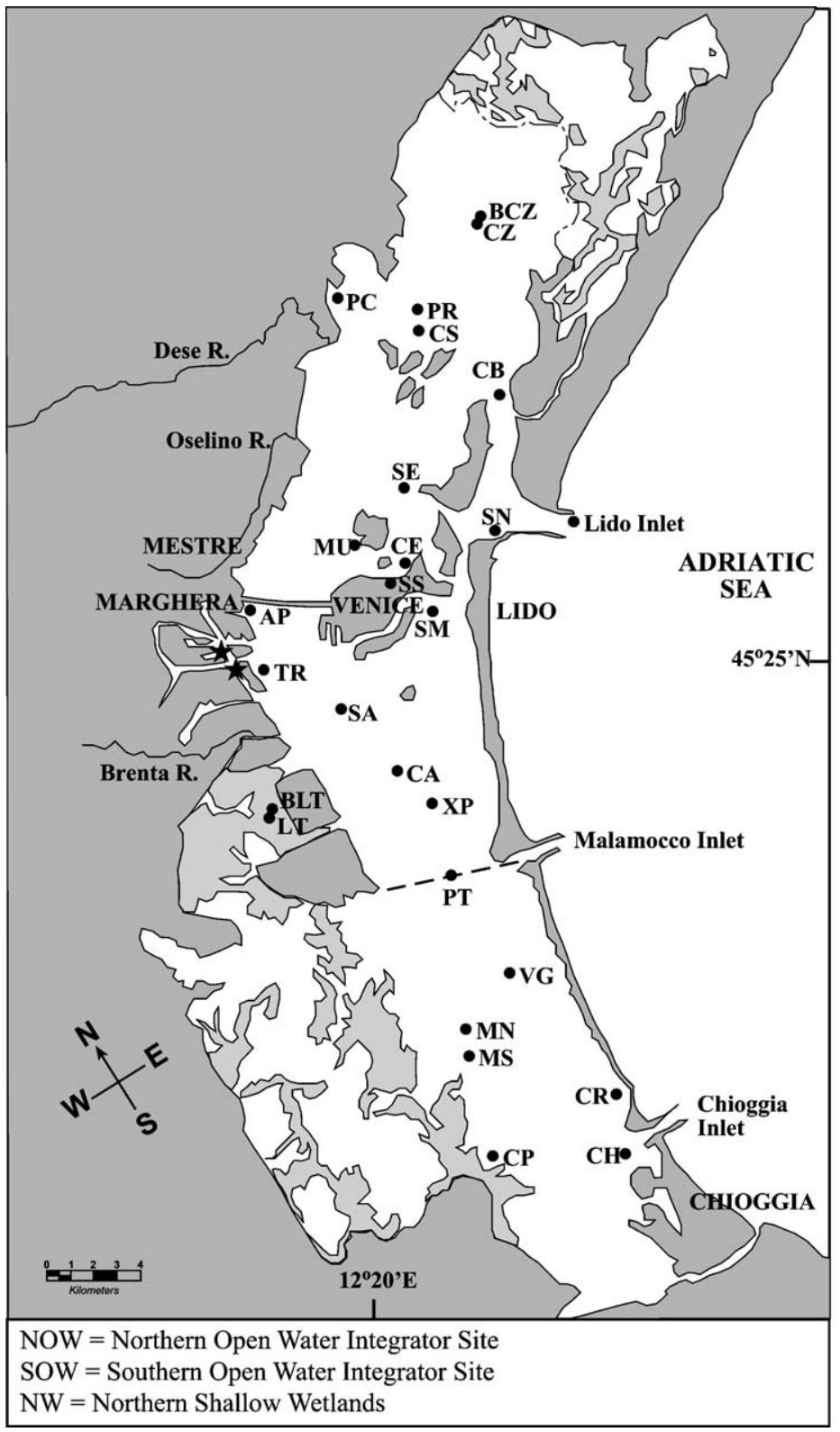

AP Ai Pili

BCZ Barena di Ca'Zane NW

BLT Barena di Lago Teneri NW

CA Campana

CB C. di Burano

NOW

CE Celestia

CH Chioggia

SOW

CP Ca'Ponti

SOW

CR Ca Roman SOW

CS Canale Silone NOW

CZ Ca'Zane NW

LT Lago Teneri NOW

MN Sette Morti N. SOW

MS Sette Morti S. SOW

MU Murano NOW

PC Palude Cona NW

PR Palude d. Rosa NW

PT C. di Petroli NOW

SS C. SS Apostoli

SA San Angelo

SE San Erasmo

SM San Marco NOW

SN San Nicolo

TR Tresse NOW

VG Val Grande sow

XP ex Poveglia NOW

Fig. 1. Sampling locations in the Venice Lagoon. 
between the sediments and the food chain (Locarnini and Presley, 1996), as they provide a large ratio of sediment surface to water volume and frequent winddriven and anthropogenic re-suspension events. Such systems also afford enhanced proximity to highly productive intertidal wetlands, where most microbial methylation (Gilmour et al., 1992) is expected to take place. Pollution of the lagoon appears to be tempered by tidal flushing. A plan to build mobile floodgates at the three lagoon portals (MOSE) to diminish the extent of tidal flooding in the city of Venice is cause for concern (Bernstein and Cecconi, 1995; Canu et al., 2001). Studies indicate that re-suspension of contaminated sediments will occur during the construction phase, and that operation of the gates could alter circulation patterns and so reduce the rate of water renewal from the Adriatic.

The lagoon is now a net exporter of sediments to the Adriatic sea, losing on average about 1.1 million $\mathrm{m}^{3}$, or $0.2 \mathrm{~cm}$ year $^{-1}$ (Day et al., 1995). The circulation patterns introduced by tidal cycling through the three openings in the barrier islands (the Lido, Malamocco, and Chioggia inlets), create regions of the lagoon that are hydrologically isolated from one another by zones of minimum lateral water movement located equidistant between the sea portals. For the purpose of this study, $\mathrm{Hg}$ concentration data shows that fluxes can be well described using a simplified two-compartment model, comprising northern and southern basins, separated by the rather deep Canale dei Petroli, which bisects the lagoon in an east-west direction. The circulation properties of the lagoon confine the majority of the $\mathrm{Hg}$ pollution to the northern basin (Critto and Marcomini, 2001).

The watershed of the lagoon is heavily populated, supporting approximately 1.5 million inhabitants, primarily engaged in agriculture, tourism, and heavy industry. With many chemical and petrochemical companies located on the western shore of the lagoon in Marghera, it is likely that there are multiple contributors to the $\mathrm{Hg}$ input to the lagoon. However, the largest single source is almost certainly the mercury cell chlor-alkali complex, which operated largely without pollution control equipment from 1951 until 1988 (Provincia di Venezia, 2002, www.provincia.venezia.it/provecolaria/epidemio/7). We were not able to find official records of the amounts of $\mathrm{Hg}$ discharged to the lagoon by the complex, but if compared with the period of production at other sites (Turner and Southworth, 1999) it would not be unreasonable to assume a discharged mass of between 100,000 and 300,000 kg.

Until very recently (Moretto et al., 2003; Bloom et al., 2004), few measurements of total $\mathrm{Hg}$ have even been reported for the water column of the lagoon, and these must be seen as of questionable accuracy, due to the absence of ultra-clean sampling and sometimes insufficiently low detection limits. In this study we apply ultra-clean sampling and analytical procedures to a comprehensive assessment of $\mathrm{Hg}$ in the Venice Lagoon, and so present the most accurate picture to date of $\mathrm{Hg}$ and $\mathrm{CH}_{3} \mathrm{Hg}$ cycling in the sediments, water and biota of this treasured yet endangered marine ecosystem.

\section{Experimental}

\subsection{Sample collection}

Water and sediment samples were collected mostly within the more polluted northern basin of the lagoon (Fig. 1). Major sampling events were in autumn (November 5, 2001, October 2-3, 2002), spring (May 10-13, 2002), summer (July 5-6, 2002), and winter (November 28, 2001, January 30, 2003 and February 20, 2003). In addition, samples of city canals were collected on March 26, 2002 and October 19-20, 2002. A limited number of samples were collected in the southern lagoon on October 31, 2002 and February 20, 2003. The site at the Adriatic outlet of the Lido portal is considered our "internal background" site in cases where the sample collection occurred during in-flowing tide (November 2001 and July 2002). A third sample considered to be representative of this site was collected from the Adriatic, off the shore rocks of the island of Lido on October 3, 2003.

Samples were considered to be from "open water integrator sites" when collected in the central basins or over deep water channels, which never emerged at low tide. The mean for the northern open water sites (Fig. 1) was made up of all sites north of Canale dei Petroli, inclusive, while the means for the southern lagoon (Fig. 1), were from sites south of the Canale dei Petroli. Samples were considered to be from 
"northern shallow wetlands" (Fig. 1) if collected from tidal pools trapped in the salt marshes (barene), or in very shallow water adjacent to the marshes, which emerged at low tide (intertidal mud flats). We included sample results from the Palude Cona site (brackish water) in the "northern shallow wetlands" mean, because it is representative of the habitat of a significant amount of the northern lagoon, and no dramatic discontinuity was seen between that site and the more saline $\mathrm{Ca}$ 'Zane to the east.

All samples were collected using ultra-clean sample handling protocols (Bloom, 1995; Bloom et al., 1999), into acid-cleaned Teflon or glass containers. Samples were collected by grab sampling at a depth of approximately $25 \mathrm{~cm}$, off the bow of a boat facing into the flow direction of the water; or in some cases by wading from shore. At each site, three independent samples were collected: one Teflon bottle was directly preserved with $0.2 \%$ (v/v) $9 \mathrm{M} \mathrm{H}_{2} \mathrm{SO}_{4}$ or $12 \mathrm{M} \mathrm{HCl}$ for the unfiltered fraction, while another was vacuumfiltered within $6 \mathrm{~h}$ through a disposable $0.4-\mu \mathrm{m}$ nitrocellulose filtration unit, and then similarly preserved for the dissolved fraction. A polyethylene bottle of unfiltered water was also collected, and kept unpreserved (dark, $0-4{ }^{\circ} \mathrm{C}$ ) for the determination of TSS.

Most sediments were collected by hand, from shallow areas using $8 \mathrm{~cm}$ diameter acrylic core tubes. The sediments from the upper 2-3 cm layer were extruded in the field, rapidly homogenized and placed into glass vials. The vials were quickly placed into a cooler held at $-5{ }^{\circ} \mathrm{C}$ until being brought to the lab freezer where they were stored at $-20{ }^{\circ} \mathrm{C}$ until analysis. In some cases, where the sediment surface was emergent, samples were collected directly from the upper 2-3 cm into the sample vial. Three sediment samples from deeper waters (Tresse, San Nicolo, Celestia) were collected in October 2001. These samples were collected using a gravity core and kept frozen until analysis.

Precipitation was collected as bulk deposition (wet plus dry), using ultra-clean Teflon sampling funnels (10 $\mathrm{cm}$ diameter), placed on rooftops around the northern lagoon. Rain collected from the funnel passed directly into a 250-ml Teflon bottle containing $10 \mathrm{ml}$ of $0.1 \mathrm{M} \mathrm{HCl}$ in deionized water, thus preserving the samples as they were collected. The sample bottle was housed in a dark plastic cylinder, to minimize the risk of solar penetration, thus degrada- tion of the $\mathrm{CH}_{3} \mathrm{Hg}$ content of the samples (Sellers et al., 1996).

Biota samples collected for unrelated programs shared sub-samples with our project. Mussels (Mytilus galloprovincialis) were hand-collected from three sites in the lagoon. For each composite sample, 20 individuals encompassing all size classes from the site were depurated in filtered seawater for $24 \mathrm{~h}$, shucked, combined, lyophilized, and homogenized using clean handling techniques. Approximately $1 \mathrm{~g}$ of this homogenate was used to obtain $\mathrm{Hg}$ speciation for this project. In November 2000, five small carnivorous fish (Zosterisessor ophiocephalus) were collected from each of four sites and Macrophytes (Ulva rigida thalli) were collected from three sites. Additional Ulva samples were collected in 2002 and feathers were collected from two cormorants (Phalacrocorax carbo) in the southern lagoon.

\subsection{Sample analysis}

All samples were extracted or digested as described below, in a low $\mathrm{Hg}$ laboratory, and analyzed using cold vapor atomic fluorescence spectrometric (CVAFS) detection (Bloom and Fitzgerald, 1988). The absolute detection limit for this instrument is approximately 0.1 pg $\mathrm{Hg}$, but all reported detection limits are determined by the variability of the measured blanks, according to the different extraction procedures. All reported data have been corrected for the mean method blank of a given extraction batch, and for changes in instrumental drift on each analytical day. Aqueous $\mathrm{CH}_{3} \mathrm{Hg}$ concentrations are also corrected for the empirically derived distillation efficiency (Bloom and von der Geest, 1995). Solids were analyzed on a wet basis to avoid artifacts and losses associated with drying. A separate aliquot was also analyzed for percent moisture, and this value was used to correct the wet-basis measurements to a dry basis. In calculating average values within a site or season, all measured results, even individual values that were below the estimated detection limits, were included in the calculation of the means and standard deviations reported.

Prior to the determination of $\mathrm{CH}_{3} \mathrm{Hg}, 45 \mathrm{ml}$ of the acidified water samples were distilled to extract $\mathrm{CH}_{3} \mathrm{HgCl}$ into a pure deionized water matrix. Sediment aliquots of $0.5 \mathrm{~g}$ were extracted into $\mathrm{CH}_{2} \mathrm{Cl}_{2}$ from a mixture of $\mathrm{H}_{2} \mathrm{SO}_{4}, \mathrm{KBr}$, and $\mathrm{CuSO}_{4}$, and then 
back into deionized water before the ethylation step, to avoid positive artifacts associated with the distillation of sediments (Bloom et al., 1997). Biota samples $(0.5 \mathrm{~g})$ were digested in $10 \mathrm{ml}$ of a $5.5 \mathrm{M}$ solution of $\mathrm{KOH}$ in methanol (Bloom, 1992). Aqueous distillates and solids digests were analyzed by aqueous phase ethylation, purging onto Carbotrap, and isothermal GC separation followed by CVAFS detection (Horvat et al., 1993; Bloom and von der Geest, 1995).

Aqueous samples to be analyzed for total $\mathrm{Hg}$ were first oxidized by adding $1 \%(\mathrm{v} / \mathrm{v})$ of $0.2 \mathrm{M} \mathrm{BrCl}$ in $12 \mathrm{M}$ $\mathrm{HCl}$ directly to the original sample bottle, and allowing overnight digestion at room temperature (Bloom and Crecelius, 1983). Sediment aliquots of $0.5 \mathrm{~g}$ were digested overnight at room temperature with $3: 1$ $\mathrm{HNO}_{3}+\mathrm{HCl}$, and then diluted to $100 \mathrm{ml}$ with deionized water prior to analysis. To determine total $\mathrm{Hg}$, aliquots of water and sediment digests ranging from 0.005 to $100 \mathrm{ml}$ (depending upon concentration) were analyzed using $\mathrm{SnCl}_{2}$ reduction, purge-and-trap on gold-coated sand and CVAFS quantification (Bloom and Crecelius, 1983; Bloom and Fitzgerald, 1988).

Total suspended solids were measured for each water sample by filtering $100-500 \mathrm{ml}$ of water through a pre-weighed $0.4 \mu \mathrm{m}$ pore-size, $47 \mathrm{~mm}$ diameter polycarbonate membrane filter, rinsing out the salts with deionized water, and drying at $65{ }^{\circ} \mathrm{C}$ for several hours prior to re-weighing. The limit of detection for TSS in a 500-ml sample was approximately $0.5 \mathrm{mg}$
$1^{-1}$. Suspended $\mathrm{Hg}$ and $\mathrm{CH}_{3} \mathrm{Hg}$ concentrations (nmol $\mathrm{g}^{-1}$ ) were calculated as the total minus the dissolved concentrations (nmol), divided by the TSS $\left(\mathrm{g} \mathrm{l}^{-1}\right)$.

\subsection{Quality assurance}

Presented in Table 1 is a summary of all replicate, matrix spike recovery, certified reference material recovery, and blank data collected during this project, indicating the overall degree of precision and accuracy represented by the data. The project-wide method detection limits (MDLs) are estimated from the pooled blank data, as $\mathrm{t}^{*} \mathrm{SD}$ of all blanks (one outlier was removed from each the $\mathrm{CH}_{3} \mathrm{Hg}$ in water and $\mathrm{CH}_{3} \mathrm{Hg}$ in sediments data sets) of a given matrix and analyte combination. These estimated MDLs can be considered to be conservative, as they represent pooled results from almost two years of sample analyses. The within-analytical-run estimated MDLs are typically about half those observed by pooling all the data.

\section{Results and discussion}

\subsection{Water column}

Before discussing the $\mathrm{Hg}$ concentrations in the lagoon, it is appropriate to understand the seasonality of suspended loading and water temperature, as these factors are quite relevant to the observed $\mathrm{Hg}$ concen-

Table 1

Summary of quality assurance measures for total $\mathrm{Hg}(\mathrm{Hg})$ and monomethyl mercury $\left(\mathrm{CH}_{3} \mathrm{Hg}\right)$ in major environmental compartments

\begin{tabular}{|c|c|c|c|c|c|c|c|}
\hline \multirow[t]{2}{*}{ Measure } & \multirow[t]{2}{*}{ Parameter } & \multicolumn{2}{|c|}{ Water $(\mathrm{pM})$} & \multicolumn{2}{|c|}{ Sediments (pmol $\left.\mathrm{g}^{-1}\right)$} & \multicolumn{2}{|c|}{ Biota $\left(\mathrm{pmol} \mathrm{g}^{-1}\right)$} \\
\hline & & $\mathrm{Hg}$ & $\mathrm{CH}_{3} \mathrm{Hg}$ & $\mathrm{Hg}$ & $\mathrm{CH}_{3} \mathrm{Hg}$ & $\mathrm{Hg}$ & $\mathrm{CH}_{3} \mathrm{Hg}$ \\
\hline \multirow[t]{4}{*}{ Blanks } & Mean & 0.25 & 0.01 & 1.0 & 0.00 & 1.5 & 0.5 \\
\hline & $\mathrm{SD}$ & 0.15 & 0.02 & 1.5 & 0.03 & 2.5 & 1.0 \\
\hline & $N$ & 35 & 34 & 14 & 17 & 6 & 6 \\
\hline & MDL & 0.35 & 0.06 & 4.5 & 0.07 & 7.5 & 3.0 \\
\hline \multirow[t]{3}{*}{ Duplicates \% Difference } & Mean & 4.4 & 7.9 & 3.5 & 9.8 & 12.5 & 7.5 \\
\hline & SD & 3.8 & 7.4 & 4.5 & 3.9 & 8.1 & 9.9 \\
\hline & $N$ & 22 & 21 & 9 & 7 & 5 & 6 \\
\hline \multirow[t]{3}{*}{ Matrix Spike \% Recovery } & Mean & 100.6 & 106.1 & 96.3 & 91.8 & 91.8 & 108.3 \\
\hline & SD & 4.8 & 8.7 & 4.9 & 11.7 & 4.8 & 13.0 \\
\hline & $N$ & 23 & 23 & 7 & 7 & 3 & 4 \\
\hline \multirow[t]{3}{*}{ CRM \% Recovery } & Mean & 91.1 & 94.6 & 96.0 & 103.0 & 98.4 & 104.0 \\
\hline & SD & 5.2 & 10.5 & 5.5 & 3.8 & 6.3 & 9.9 \\
\hline & $N$ & 12 & 14 & 5 & 4 & 4 & 4 \\
\hline
\end{tabular}

$\mathrm{SD}=$ standard deviation, $N=$ number of results, $\mathrm{MDL}=$ method detection limit, $\mathrm{CRM}=$ certified reference material. 
trations and degree of methylation. Seasonal averages for water temperature and TSS for all samples collected from the northern open water integrator sites are shown on Fig. 2. The temperature in the lagoon shows an expected seasonal pattern, with highest values in the summer reaching $25-27{ }^{\circ} \mathrm{C}$, while wintertime lows were typically in the range of $4-7^{\circ} \mathrm{C}$. Water entering the Lido inlet from the Adriatic Sea at flood tide was more narrowly constrained in temperature throughout the year, ranging from 16 to $19{ }^{\circ} \mathrm{C}$. This indicates that despite the very thorough tidal flushing of the lagoon, its shallow waters promote rapid temperature equilibration with the air. Temperatures are evenly distributed in any season due to the thorough tidal mixing. Those collected in the shallowest wetlands were typically only $1-3{ }^{\circ} \mathrm{C}$ higher in summer and colder in winter than were the averages for the deeper water sites shown here.
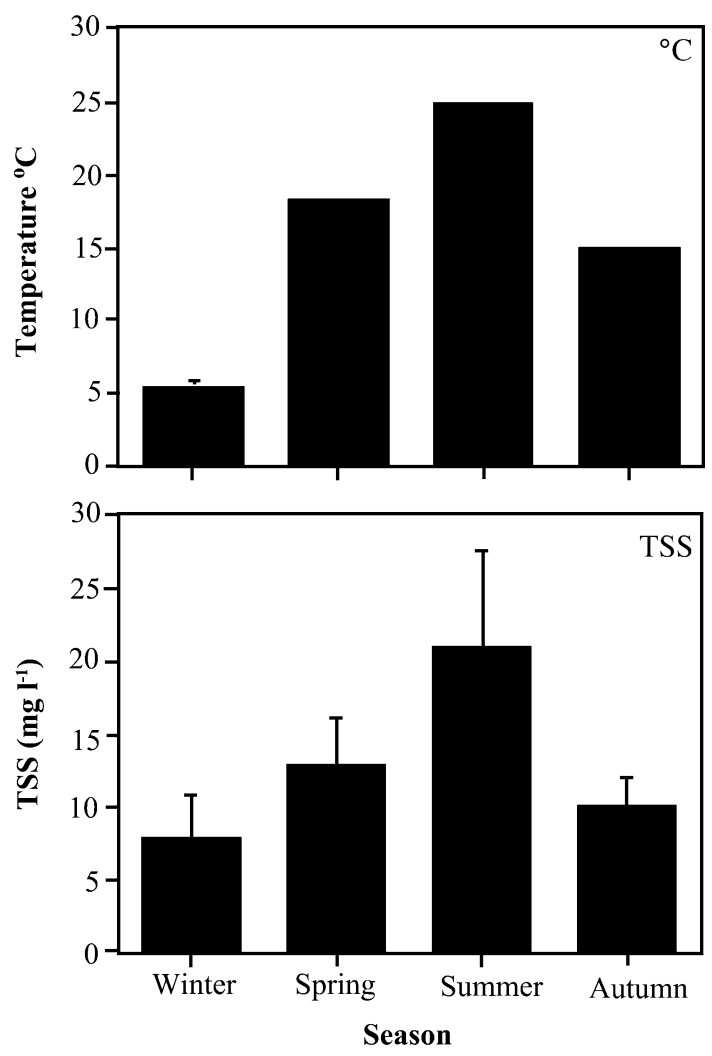

Fig. 2. Mean water temperature and total suspended solids (TSS) at the time of sample collection. Error bars are the standard error $(\mathrm{SE}=\mathrm{SD} \sqrt{n})$ for $8-13$ sites throughout the lagoon collected over a 1-2 day period.
The suspended solids in the water column show the same seasonal pattern as temperature, with highest average values in summer and lowest values in winter. Total suspended solids variability between sites in a given season was high, with standard deviations approaching $100 \%$ in some seasons. As expected, the average TSS values for the northern shallow wetlands were about twice as high as the values shown for the open water sites (Fig. 2 and Table 4). It is probable that higher TSS concentrations in the warmer months represent increased anthropogenic activities during these periods.

Total $\mathrm{Hg}$ concentrations and the fraction methylated varied dramatically within the lagoon (Table 2), revealing about 5-10 times higher total $\mathrm{Hg}$ levels in the northern basin compared to the southern areas. These are, in turn, about $50 \%$ higher than inflowing water from the Adriatic Sea. Highest average values for total $\mathrm{Hg}$ were observed in the urban canals of Venice, and were more than twice as contaminated as the canals in the industrial district of Marghera. This trend agrees with preliminary data presented previously (Ugo et al., 2001). Highest $\mathrm{CH}_{3} \mathrm{Hg}$ concentrations in the lagoon, as well as the highest percentages in the methylated form, were observed in waters from the shallow contaminated wetlands. The observed $\mathrm{Hg}$ concentrations flowing into the Lido inlet, though the lowest in the lagoon, do not represent true background levels, as they are six times higher yet than values reported for the open Adriatic (Horvat et al., 2001). This is not surprising, as up to $28 \%$ of the water flowing in at Lido appears to be recycled lagoon water from the previous tidal cycle (Marcomini et al., 1995).

Much of the observed variability in $\mathrm{Hg}$ concentration is attributable to the higher average levels of TSS in the northern basin, combined with the greater concentrations of $\mathrm{Hg}$ on the sediments in this more anthropogenically impacted region. Dissolved $\mathrm{Hg}$ concentrations were generally much more similar throughout the lagoon. The mean total $\mathrm{Hg}$ concentration for the three most important river inputs to the lagoon (the Dese, Oselino, and Naviglio Brenta) was $59 \mathrm{pM}$, which is somewhat lower than the concentrations seen in the lagoon, while the mean $\mathrm{CH}_{3} \mathrm{Hg}$ concentration of $0.99 \mathrm{pM}$ was higher than all areas of the lagoon excepting the wetlands. The relatively high methylated fraction in the riverine samples is typical of fresh water environments (Bloom et al., 1991; Hurley 
Table 2

Mean water column mercury $(\mathrm{Hg})$ speciation in various compartments of the Venice Lagoon

\begin{tabular}{|c|c|c|c|c|c|c|c|c|}
\hline \multirow[t]{2}{*}{ Region of lagoon } & \multicolumn{3}{|c|}{ Total Hg (pM) } & \multicolumn{3}{|c|}{ Monomethyl Hg (pM) } & \multicolumn{2}{|c|}{$\%$ Methylated } \\
\hline & UF & $\mathrm{F}$ & $\%$ diss & UF & $\mathrm{F}$ & $\%$ diss & UF & $\mathrm{F}$ \\
\hline North, wetlands & 145 & 10.4 & 12.9 & 1.03 & 0.24 & 34.7 & 1.13 & 2.38 \\
\hline SE $(n=16)$ & 43 & 1.1 & 2.2 & 0.25 & 0.05 & 6.0 & 0.34 & 0.43 \\
\hline North, open water & 74 & 7.3 & 14.8 & 0.35 & 0.10 & 33.3 & 0.69 & 1.49 \\
\hline SE $(n=23)$ & 16 & 0.6 & 1.7 & 0.07 & 0.02 & 4.8 & 0.19 & 0.33 \\
\hline Ai Pili (Marghera) & 281 & 11.4 & 8.3 & 0.56 & 0.14 & 33.9 & 0.22 & 1.22 \\
\hline $\mathrm{SE}(n=6)$ & 113 & 2.6 & 3.8 & 0.21 & 0.05 & 8.8 & 0.03 & 0.24 \\
\hline Industrial canals & 134 & 15.9 & 12.5 & 0.46 & 0.13 & 30.2 & 0.37 & 0.78 \\
\hline $\mathrm{SE}(n=8)$ & 29 & 2.9 & 3.4 & 0.12 & 0.04 & 6.0 & 0.09 & 0.13 \\
\hline City canals & 470 & 10.8 & 4.1 & 1.40 & 0.28 & 22.8 & 0.43 & 2.80 \\
\hline SE $(n=40)$ & 94 & 1.2 & 0.7 & 0.18 & 0.04 & 2.2 & 0.05 & 0.28 \\
\hline South, open water & 15.7 & 5.2 & 39.2 & 0.13 & 0.08 & 56.2 & 1.10 & 1.60 \\
\hline $\mathrm{SE}(n=10)$ & 2.7 & 0.5 & 5.3 & 0.02 & 0.02 & 9.1 & 0.26 & 0.42 \\
\hline Adriatic inflow & 11.0 & 4.8 & 44.9 & 0.07 & 0.05 & 67.8 & 0.68 & 0.92 \\
\hline $\mathrm{SE}(n=5)$ & 1.9 & 1.0 & 8.9 & 0.03 & 0.02 & 28.1 & 0.19 & 0.20 \\
\hline Precipitation (North) & 104 & $n d$ & $n d$ & 0.41 & nd & $n d$ & 0.65 & nd \\
\hline $\mathrm{SE}(n=43)$ & 15 & nd & nd & 0.10 & nd & nd & 0.18 & nd \\
\hline Rivers (North) & 59 & 6.6 & 17.4 & 0.99 & 0.18 & 33.5 & 2.22 & 2.30 \\
\hline $\mathrm{SE}(n=10)$ & 17 & 0.5 & 3.2 & 0.35 & 0.05 & 11.2 & 0.96 & 0.59 \\
\hline
\end{tabular}

et al., 1995), and likely reflects watershed runoff, since $\mathrm{CH}_{3} \mathrm{Hg}$ is less strongly bound to soil and humus than is inorganic $\mathrm{Hg}$.

A seasonal comparison was made of $\mathrm{Hg}$ speciation in the water column by pooling all results from the northern open water integrator sites for each sampling period (5-9 results per season). Total $\mathrm{Hg}$ was seen to vary by roughly $50 \%$ (Fig. 3), with the trend reflecting the pattern seen in TSS over the year (Fig. 2). By contrast, dissolved $\mathrm{Hg}$ showed virtually no pattern, with almost exactly the same mean concentration in each season. For $\mathrm{CH}_{3} \mathrm{Hg}$, the shape of the trend was similar, but the relative difference between seasons was much more dramatic, with the summer time maximum exceeding the winter minimum by a factor of five. This pattern is not unexpected, as $\mathrm{CH}_{3} \mathrm{Hg}$ formation is largely a microbial process (Gilmour et al., 1992), which should increase as metabolic activity increases in the warmer months.

\subsection{Mercury speciation in rain}

Shown on Fig. 4 are the average seasonal concentrations for total $\mathrm{Hg}$ and $\mathrm{CH}_{3} \mathrm{Hg}$ over the northern lagoon. Total $\mathrm{Hg}$ varied by about $50 \%$ throughout the year, with the peak mean concentration in the spring, while $\mathrm{CH}_{3} \mathrm{Hg}$ showed a strong pattern favoring highest levels in the winter $\left(1.64 \% \mathrm{CH}_{3} \mathrm{Hg}\right)$ and dropping nearly to zero in the summer $\left(0.09 \% \mathrm{CH}_{3} \mathrm{Hg}\right)$. This pattern has been observed in other environments (Bloom et al., 1995) and appears curiously opposed, though mechanistically unrelated to the trend seen in the water column. Precipitation over the lagoon is relatively evenly distributed throughout the year, meaning that the pooled seasonal concentration data shown on Fig. 4 can be transformed into deposition data. We utilized the long-term average rainfall value of $83 \mathrm{~cm}$ year $^{-1}$ (Zaggia et al., 2001) and multiplied this value by the mean $\mathrm{Hg}$ concentration. Total $\mathrm{Hg}$ deposition over the year is estimated to be $86 \mathrm{nmol}$ $\mathrm{m}^{-2}$ year $^{-1}$, which is comparable to values $(20-110$ nmol $\mathrm{m}^{-2}$ year ${ }^{-1}$ ) seen across the United States between 1995 and 2002 (Vermette et al., 1995; Mercury Deposition Network, 2003, www.nadp.sws .uiuc.edu). Total $\mathrm{CH}_{3} \mathrm{Hg}$ deposition was $0.34 \mathrm{nmol}$ $\mathrm{m}^{-2}$ year $^{-1}$, or $0.40 \%$ of the total.

\subsection{Speciation and dynamics of $\mathrm{Hg}$ in the urban canals}

Although the urban canal system of Venice is far too complex to study in detail within a synoptic 

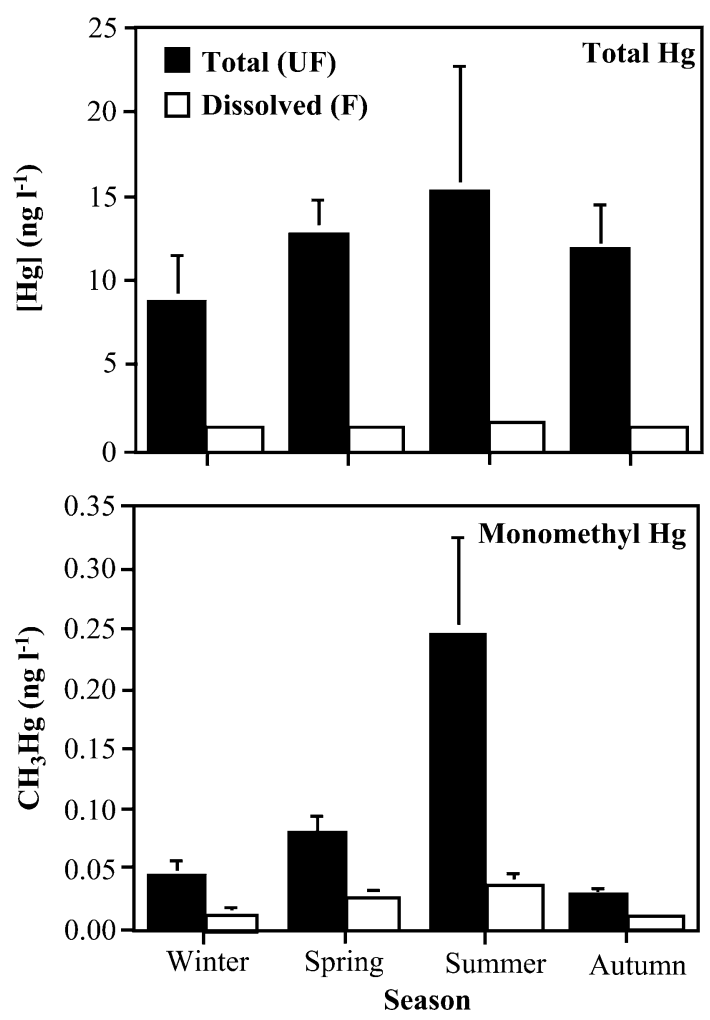

Fig. 3. Seasonal variation in the mean total $\mathrm{Hg}$ and methyl $\mathrm{Hg}$ concentrations (black bars are unfiltered, white bars $0.4 \mu \mathrm{m}$ filtered) in the northern open water integrator sites. Error bars are the standard error $(\mathrm{SE}=\mathrm{SD} \sqrt{n})$ for five to eight sites per season.

project such as this, we undertook two investigations to obtain an overview as an aid to future studies. The first study sought to look at a canal sub-system centered on Rio Marin. Samples were collected synoptically (at the slack periods, at maximum high tide and low tide) at four connected branches leading deeply into the labyrinth. We hypothesize the flushing regime becomes poorer with each branch away from the lagoon. This data, shown on Table 3, indicates an order of magnitude increase in both $\mathrm{Hg}$ and $\mathrm{CH}_{3} \mathrm{Hg}$ concentrations in the innermost branches compared to the open lagoon. A second experiment was conducted in the Canale SS Apostoli. In this experiment (Fig. 5), samples were collected every $2 \mathrm{~h}$ over a 24 -h period, in a location with a strong tidal cycle of approximately $85 \mathrm{~cm}$ total displacement. Total $\mathrm{Hg}$ in the water column was found to be strongly and inversely correlated with tide height. Total Hg concentrations were lowest, and quite similar to typical open lagoon values at the peak of high tide, and then increased by approximately $3-5$-fold by the time lowest tide points were reached. Over the same cycle, $\mathrm{CH}_{3} \mathrm{Hg}$ concentrations were found to vary only slightly. Both of these experiments indicate a source of $\mathrm{Hg}$ within the canal system, which is diluted by tidal flushing. We believe that the internal source is seepage of raw domestic sewage from the septic tanks of residences and hotels in the city (Pavoni et al., 1990).

\subsection{Mercury speciation in suspended and settled sediments}

Table 4 summarizes the mean suspended $\mathrm{Hg}$ speciation in various compartments of the lagoon. With the exception of the high concentrations seen in the industrial canals and Ai Pili, which are in the vicinity of the Marghera petrochemical zone, the
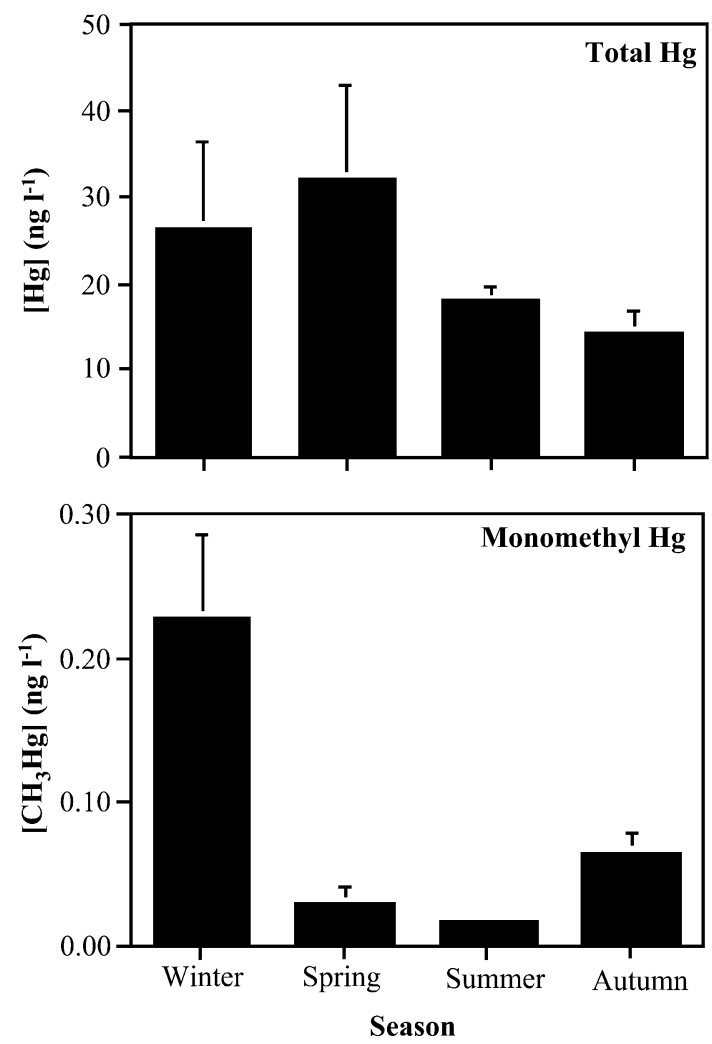

Fig. 4. Seasonal variation in the mean total $\mathrm{Hg}$ and monomethyl $\mathrm{Hg}$ concentrations in northern lagoon rain samples (samples were not filtered). Error bars are the standard error $(\mathrm{SE}=\mathrm{SD} \sqrt{n})$ for $8-15$ samples per season. 
Table 3

Mean mercury concentrations in Venice City canals (2-14 points per mean)

\begin{tabular}{llcl}
\hline Site & Filtration & \multicolumn{2}{c}{ Mercury, pM } \\
\cline { 3 - 4 } & & Total & Monomethyl \\
\hline Bacino San Marco (open) & unfiltered & 45.5 & 0.21 \\
four seasons & $0.45 \mu$ & 5.9 & 0.09 \\
Canale Giudeca $\left(1^{\circ}\right)$ & unfiltered & 110 & 0.61 \\
Winter, Summer & $0.45 \mu$ & 10.5 & 0.12 \\
Canale Grande $\left(2^{\circ}\right)$ & unfiltered & 443 & 1.66 \\
Winter, Summer & $0.45 \mu$ & 11.2 & 0.29 \\
Rio Marin $\left(3^{\circ}\right)$ & unfiltered & 756 & 1.35 \\
Winter, Summer & $0.45 \mu$ & 15.0 & 0.34 \\
Rio Tentor $\left(3^{\circ}\right)$ & unfiltered & 424 & 1.08 \\
four seasons & $0.45 \mu$ & 8.9 & 0.18 \\
Canale SS. Apostoli $\left(3^{\circ}\right)$ & unfiltered & 551 & 1.32 \\
Autumn, Summer & $0.45 \mu$ & 8.8 & 0.16 \\
Rio dei Miracoli $\left(4^{\circ}\right)$ & unfiltered & 418 & 1.62 \\
Summer & $0.45 \mu$ & 6.4 & 0.27 \\
Rio dei Frari $\left(4^{\circ}\right)$ & unfiltered & 216 & 1.54 \\
Winter, Summer & $0.45 \mu$ & 13.1 & 0.50 \\
\hline
\end{tabular}

The degree indicates relative canal size ( $1^{\circ}$ being biggest).

suspended $\mathrm{Hg}$ chemistry is relatively uniform throughout the lagoon, with an average value of about 5.0 nmol g ${ }^{-1} \mathrm{Hg}$ and $0.04 \mathrm{nmol} \mathrm{g}^{-1} \mathrm{CH}_{3} \mathrm{Hg}$. The average values for total $\mathrm{Hg}$ are higher than those found in the San Francisco Bay estuary which averages $1.8 \mathrm{nmol}$ $\mathrm{g}^{-1}$ (Conaway et al., 2003) and are more consistent with values found in other estuaries of Europe (Leemakers et al., 1995). In the less polluted southern basin, and in the incoming waters at the Lido port, concentrations were only about $20-30 \%$ lower than in the northern lagoon. Thus, the overall relationship of total water column Hg and TSS is primarily one of the amount of suspended matter, with only a small additional influence contributed by the concentration of the $\mathrm{Hg}$ on the particles. The seasonal patterns of $\mathrm{Hg}$ speciation on the suspended matter can be seen in Fig. 6. Even more evident than in the water column, there is little if any seasonal variability in the average concentration of total $\mathrm{Hg}$ on suspended matter from the northern lagoon, while a 5-fold peak in $\mathrm{CH}_{3} \mathrm{Hg}$ is observed during the summer.

Total $\mathrm{Hg}$ in suspended matter (Table 4) is similar $(10-20 \%$ higher) to that found in surface sediments (Table 5) from equivalent regions. Monomethyl mercury, however, is 4-10 times higher in the suspended matter than in the surface sediments of equivalent sites. The seasonal pattern of $\mathrm{CH}_{3} \mathrm{Hg}$ in the surface sediments of the lagoon (Fig. 7) does not show the same pattern as is seen in the water column and suspended solids. In the sediments, the peak is only double the autumn minimum, and it is in spring rather than summer. This pattern for sediment Hg methylation is similar to that observed in Lavaca Bay (Bloom et al., 1999, 2003), where a sharp and dramatic peak in methylation was seen in early spring, just as the water temperatures began to rise. It is as yet unclear why the peak in sediment $\mathrm{Hg}$ methylation should precede the peak in observed water column and suspended $\mathrm{CH}_{3} \mathrm{Hg}$. We suspect it may be due to the summertime production of large quantities of dissolved $\mathrm{CH}_{3} \mathrm{Hg}$ in the productive salt marshes and their associated algal mats, which then leach into the water column during the tidal flushing cycle. Once transported to the bulk water column, this dissolved $\mathrm{CH}_{3} \mathrm{Hg}$ may then adsorb to the in situ suspended matter, so increasing its concentration above that of the bottom sediment.

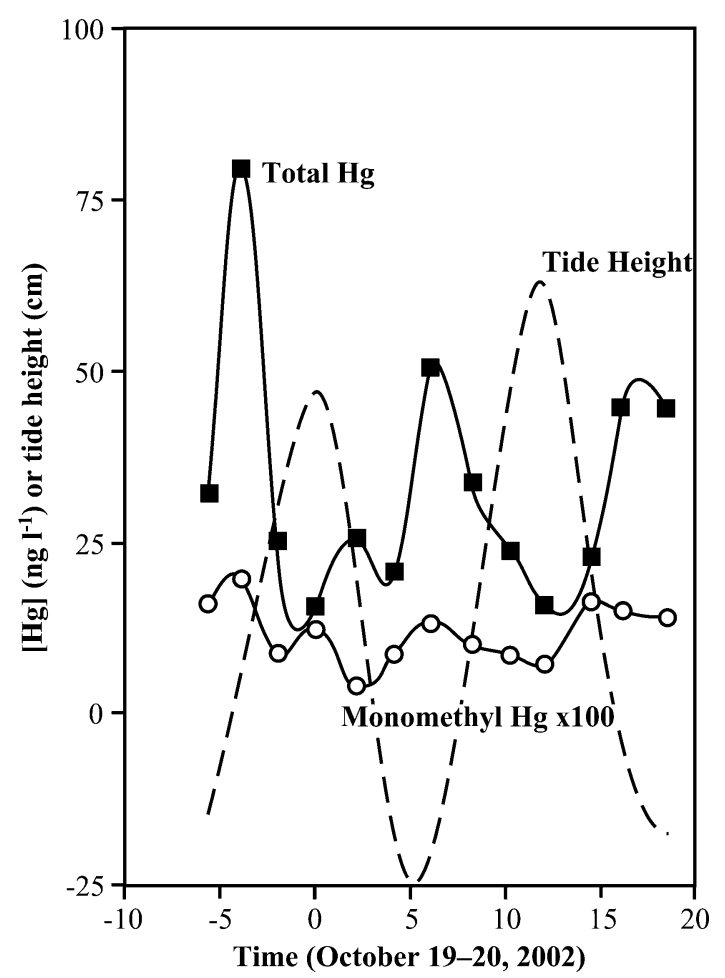

Fig. 5. Tidal flushing of total $\mathrm{Hg}$ (black squares), and monomethyl $\mathrm{Hg}$ (white circles) as a function of tide height (dotted line) at Ponte San Canzian in the Canale SS Apostoli, Venice. 
Table 4

Mercury speciation in suspended solids in the water column of the Venice Lagoon

\begin{tabular}{|c|c|c|c|c|}
\hline \multirow[t]{2}{*}{$\begin{array}{l}\text { Region of } \\
\text { lagoon }\end{array}$} & \multirow[t]{2}{*}{$\begin{array}{l}\text { Susp. solids } \\
{\mathrm{mg} 1^{-1}}\end{array}$} & \multicolumn{3}{|c|}{$\begin{array}{l}\text { Mercury Concentrations, } \\
\mathrm{nmol} \mathrm{g}^{-1} \text { dry basis }\end{array}$} \\
\hline & & Total & Monomethyl & $\%$ Methylated \\
\hline North, wetlands & 26.1 & 5.79 & 0.045 & 0.98 \\
\hline SE $(n=16)$ & 6.8 & 0.99 & 0.019 & 0.35 \\
\hline $\begin{array}{l}\text { North, } \\
\text { open water }\end{array}$ & 10.8 & 5.86 & 0.033 & 0.62 \\
\hline SE $(n=23)$ & 1.3 & 0.77 & 0.013 & 0.23 \\
\hline $\begin{array}{l}\text { Ai Pili } \\
\text { (Marghera) }\end{array}$ & 19.1 & 16.05 & 0.025 & 0.17 \\
\hline $\operatorname{SE}(n=6)$ & 8.2 & 5.31 & 0.008 & 0.04 \\
\hline $\begin{array}{r}\text { Industrial } \\
\text { Canals }\end{array}$ & 11.8 & 16.23 & 0.049 & 0.32 \\
\hline $\operatorname{SE}(n=8)$ & 4.0 & 3.81 & 0.018 & 0.09 \\
\hline $\begin{array}{l}\text { South, } \\
\text { open water }\end{array}$ & 3.0 & 3.79 & 0.033 & 1.04 \\
\hline $\operatorname{SE}(n=10)$ & 0.6 & 0.67 & 0.012 & 0.36 \\
\hline Adriatic inflow & 1.9 & 4.50 & 0.041 & 1.41 \\
\hline $\mathrm{SE}(n=5)$ & 0.5 & 0.83 & 0.006 & 0.46 \\
\hline Rivers (North) & 17.1 & 4.35 & 0.094 & 2.21 \\
\hline $\operatorname{SE}(n=10)$ & 7.5 & 1.00 & 0.038 & 1.13 \\
\hline
\end{tabular}

$\mathrm{SE}=$ standard error $=\mathrm{SD} / \sqrt{n}, n=$ number of samples.

\subsection{Mercury transfer through the food chain}

Although a limited number of biota samples were analyzed, clear trends are apparent. Monomethyl mercury shows a greater than seven orders of magnitude bioconcentration factor (BCF) from the water column up through the fish-eating cormorant population of the lagoon (Table 6). The biggest concentration occurs at the bottom of the food chain, where a five orders of magnitude increase is seen from water to suspended matter, or "seston" (Watras and Bloom, 1992). The $\mathrm{CH}_{3} \mathrm{Hg}$ BCF from water to macrophytes is almost exactly the same as that seen for seston, supporting its use as the measure of the first step in the aquatic food chain. From seston to the small fish and mussels we see an additional order of magnitude leap in concentrations, followed by one more order of magnitude going upward to the fishconsuming birds. The data from mussels indicates that the total $\mathrm{Hg}$ concentrations in the lagoon appear to be higher than in any other site monitored around the Italian coast, and approximately an order of magnitude higher than at a background site such as Ischia (Giordano et al., 1991).
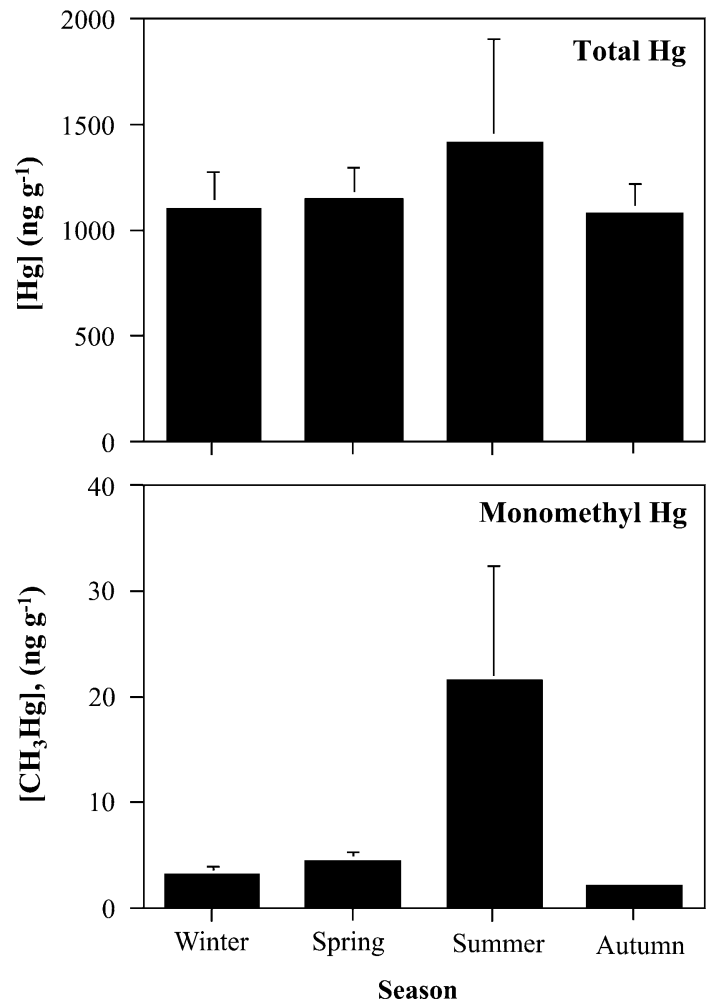

Fig. 6. Seasonal variability in total $\mathrm{Hg}$ and monomethyl $\mathrm{Hg}$ concentrations on suspended matter from the northern lagoon open water integrator sites. Error bars are the standard error $(\mathrm{SE}=\mathrm{SD} \sqrt{n})$ for five to eight sites per season.

\subsection{Simplified mass balance for $\mathrm{Hg}$ in the lagoon}

Although not enough data was collected in the southern lagoon to allow a rigorous mass balance to be calculated, it is still interesting to make an estimate with the current data. Since the highest Hg concen-

Table 5

Mercury $(\mathrm{Hg})$ speciation in surface $(0-3 \mathrm{~cm})$ sediments of the Venice Lagoon

\begin{tabular}{lcll}
\hline Region of lagoon & \multicolumn{3}{c}{ Surface Sediment $\mathrm{Hg}, \mathrm{nmol} \mathrm{g}^{-1}$ dry basis } \\
\cline { 2 - 4 } & Total $\mathrm{Hg}$ & Monomethyl $\mathrm{Hg}$ & $\%$ Methylated \\
\hline North, wetlands & 4.07 & 0.0078 & 0.302 \\
SE $(n=32)$ & 0.45 & 0.0011 & 0.094 \\
North, open water & 3.20 & 0.0020 & 0.080 \\
SE ( $n=3)$ & 1.31 & 0.0006 & 0.023 \\
Ai Pili (Marghera) & 17.0 & 0.0068 & 0.053 \\
SE $(n=10)$ & 4.7 & 0.0006 & 0.006 \\
\hline
\end{tabular}

$\mathrm{SE}=$ standard error $=\mathrm{SD} / \sqrt{n}, n=$ number of samples. 

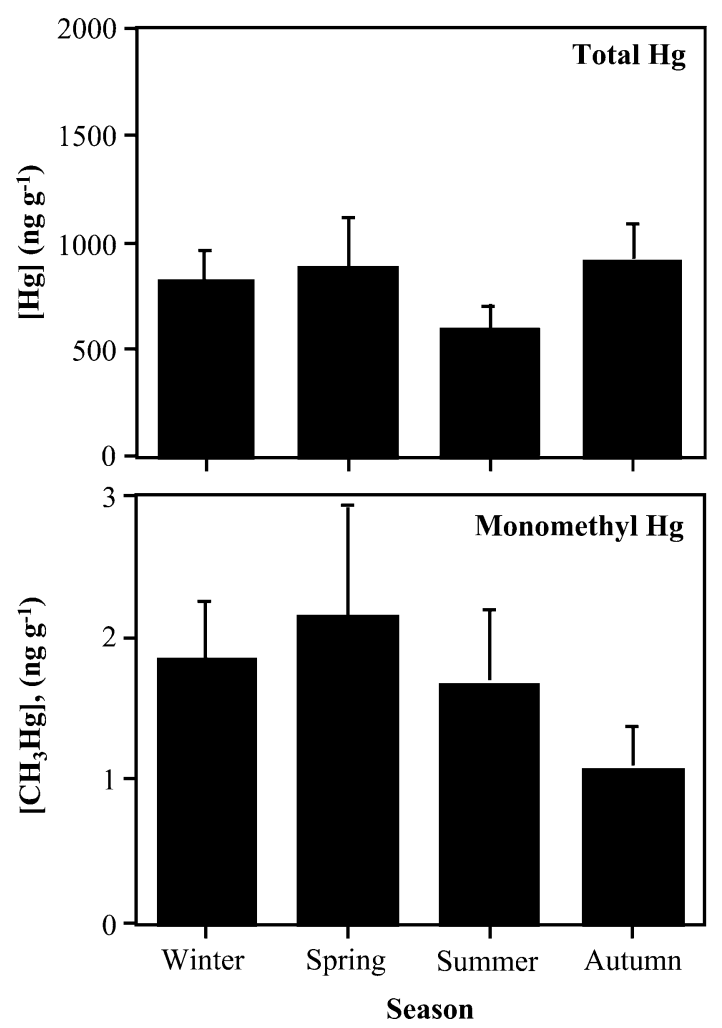

Fig. 7. Seasonal variation of total $\mathrm{Hg}$ and monomethyl $\mathrm{Hg}$ concentrations in surface sediments from the northern lagoon. Error bars are the standard error $(\mathrm{SE}=\mathrm{SD} \sqrt{n})$ for three to five sites per season.

trations and fluxes occurred in the contaminated northern basin, where we do have extensive data, it is unlikely that any errors in the southern lagoon budget will seriously impact the overall mass balance. The mass balance is comprised as a yearly average, by taking appropriate mean $\mathrm{Hg}$ concentrations over an area and throughout the year, and then multiplying by mean water or sediment fluxes extracted from the literature or estimates. Although the lagoon properly consists of three hydrodynamically distinct basins, to better match our data set we assumed two regions of distinct chemistry, the northern (more contaminated) section comprising approximately $64.8 \%$ of the area of the lagoon, and the southern section, comprising $35.2 \%$. The dividing point was the Canale Petroli, the point at which a sudden drop in aqueous $\mathrm{Hg}$ concentrations can be seen going from north to south.

For this illustration we further assume that the average water concentration in the northern basin is exchanged primarily through the Lido mouth, and the average water concentration in the southern section is exchanged primarily at Chioggia. Water exiting Malamocco would be a mixture of half northern section and half southern section concentrations. Thus, taking the literature values for average annual exchange through the ports of $5.6 \times 10^{10} \mathrm{~m}^{3}$ year $^{-1}$ $(40 \%)$ at Lido, $5.6 \times 10^{10} \mathrm{~m}^{3}$ year $^{-1}(40 \%)$ at Malamocco, and $2.8 \times 10^{10} \mathrm{~m}^{3}$ year $^{-1}(20 \%)$ at Chioggia (Critto and Marcomini, 2001), these flows are recalculated as $8.4 \times 10^{10} \mathrm{~m}^{3}$ year $^{-1}(60 \%)$ of northern characteristic water and $5.6 \times 10^{10} \mathrm{~m}^{3}$ year $^{-1}$ $(40 \%)$ of southern characteristic water. A further key consideration is the flux of sediments lost from the lagoon, put to be $1.1 \times 10^{6} \mathrm{~m}^{3}$ year $^{-1}$ (Day et al., 1995). Using a mean wet density of $2.04 \mathrm{~g} \mathrm{~cm}^{-3}$ and an average dry fraction of $53.5 \%$, this results in a total of $1.22 \times 10^{13} \mathrm{~g} \mathrm{year}^{-1}$ of sediment on a dry basis. For rainfall contribution we used the long-term mean precipitation in the northern lagoon of $83 \mathrm{~cm}_{\text {year }}^{-1}$

Table 6

Mean mercury $(\mathrm{Hg})$ speciation, bioconcentration factor $(\mathrm{BCF})$, and sediment factor (Kd) with respect to dissolved aqueous concentrations at various trophic levels in the Venice Lagoon

\begin{tabular}{|c|c|c|c|c|c|c|}
\hline \multirow[t]{2}{*}{ Trophic level } & \multirow[t]{2}{*}{$n$} & \multicolumn{2}{|c|}{ Mercury level, $\mathrm{nmol} \mathrm{g}^{-1}$} & \multirow[t]{2}{*}{ Percent methylated } & \multicolumn{2}{|c|}{ Aqueous $\log (\mathrm{BCF}$ or $\mathrm{Kd})$} \\
\hline & & Total Hg & Monomethyl $\mathrm{Hg}$ & & Total $\mathrm{Hg}$ & Monomethyl Hg \\
\hline Water, dissolved & 39 & $9.4 \times 10^{-6}$ & $1.7 \times 10^{-7}$ & 1.76 & $n c$ & $n c$ \\
\hline Sediment (dry basis) & 32 & 4.07 & 0.0078 & 0.30 & 5.64 & 4.67 \\
\hline Seston (dry basis) & 39 & 5.83 & 0.0389 & 0.80 & 5.79 & 5.37 \\
\hline Rock algae (wet basis) & 5 & 0.91 & 0.0333 & 4.14 & 4.99 & 5.30 \\
\hline Mussels (wet basis) & 3 & 1.76 & 0.690 & 37.9 & 5.27 & 6.62 \\
\hline Small fish (wet basis) & 20 & 0.89 & 0.850 & 94.2 & 4.98 & 6.71 \\
\hline Cormorant feathers & 2 & 10.98 & 10.81 & 98.2 & 6.07 & 7.82 \\
\hline
\end{tabular}

$n=$ number of samples, $n c=$ not calculated. 
(Zaggia et al., 2001) or $4.57 \times 10^{8} \mathrm{~m}^{3}$ year $^{-1}$ over the whole lagoon. This we multiplied by the average mean bulk precipitation concentrations. Similarly, the average yearly river flow into the lagoon, for all rivers, is $1.12 \times 10^{9} \mathrm{~m}^{3}$ year $^{-1}$ (Zuliani et al., 2001), which was multiplied by the mean concentrations observed for the three major rivers to the lagoon. With no data for direct industrial inputs to the lagoon, we used the published value of $36 \mathrm{~kg}$ year $^{-1}$ total $\mathrm{Hg}$ (Critto and Marcomini, 2001), and assumed 1\% of that value was $\mathrm{CH}_{3} \mathrm{Hg}$.

To calculate the mean re-suspension flux of sediments, we assumed again two boxes, the northern box having a mean surface sediment concentration based on our measurements. However, since we have no sediment values from the southern lagoon, we employed the average value of $2.20 \mathrm{nmol} \mathrm{g}^{-1}$ from that region taken from Critto and Marcomini (2001). For $\mathrm{CH}_{3} \mathrm{Hg}$ in the southern lagoon, we then assumed the same percentage as was found in the northern lagoon sediments. To estimate the flux of sediment from each region, we had to, in some way, take into account that the northern lagoon has much more resuspension than the southern region. This was estimated by ratio of the net average (i.e., mean value minus mean value incoming from the Adriatic) open water TSS values in the northern region $\left(8.9 \mathrm{mg}^{-1}\right)$ and the southern lagoon $\left(1.1 \mathrm{mg}^{-1}\right)$, and weighting for the respective area of the two basins. When this is done, we estimated that $92.4 \%$ of re-suspension $\left(1.13 \times 10^{12} \mathrm{~g} \mathrm{year}^{-1}\right)$ occurs in the northern basin and $7.6 \%$ from the southern basin $\left(9.27 \times 10^{10} \mathrm{~g}\right.$ year $^{-1}$ ).

Three smaller fluxes are more speculative, but all are so small as to be trivial in the final calculations. We estimated the amount of $\mathrm{Hg}$ removed from the lagoon by fishing, using the mean concentration in our fish, plus mussels, multiplied by an estimate of $1.94 \times 10^{6} \mathrm{~kg}$ year $^{-1}$ harvested from the lagoon (Granzotto et al., 2001). To estimate the flux of $\mathrm{Hg}$ from the city canals, we measured the surface area of the populated islands (Venice, Murano, Giudecca, Burano, and a section of Lido), which is $11.2 \mathrm{~km}^{2}$, and assumed (by visual estimate) that $5 \%$ of the city islands are canals. This provided an estimate of 0.55 $\mathrm{km}^{2}$ of canal surface, or $0.1 \%$ of the total lagoon surface area. For the purpose of this example, we simply assumed that the flow through the canal systems is therefore $0.1 \%$ of the total flow through the lagoon, or $1.4 \times 10^{8} \mathrm{~m}^{3}$ year $^{-1}$. This value was multiplied by the net $\mathrm{Hg}$ concentrations (mean concentrations in canals minus mean concentration in northern open waters) to obtain the flux estimate. Finally, the loss of $\mathrm{Hg}$ by volatilization was estimated from three measurements of $\mathrm{Hg}^{\mathrm{o}}$ in the lagoon waters, and the relationship $F=\left(K^{*}\left(C_{\mathrm{a}} / H-C_{\mathrm{w}}\right)\right)^{*} \mathrm{~A}$ (Vandal et al., 1991) where $F$ is the evasion flux in $\mathrm{kg}$ year $^{-1}, K$ is the "transfer velocity," which is dependent on the wind speed $(u), C_{\mathrm{a}}$ is the concentration of the $\mathrm{Hg}^{\mathrm{o}}$ in air (we used a typical northern hemisphere value of 2 $\left.\mathrm{ng} \mathrm{m}^{-3}\right), H$ is the dimensionless Henry's Law distribution coefficient for $\mathrm{Hg}^{\mathrm{O}}$ between air and water at room temperature $(0.3), C_{\mathrm{w}}$ is the mean $\mathrm{Hg}^{\mathrm{O}}$ concentration in the water, and $A$ is the area of the lagoon. The empirically derived wind dependence of $K=0.45 u^{1.64}$ and the mean wind speed in the lagoon is $5 \mathrm{~m} \mathrm{~s}^{-1}$ (Institute of Marine Biology, Venice, 2002, www.ibm.ve.cnr.it). The same calculation can be applied to $\mathrm{CH}_{3} \mathrm{Hg}$ as $\mathrm{Hg}^{\mathrm{O}}$, but because of the low concentration of $\mathrm{CH}_{3} \mathrm{Hg}$ and the very low $\mathrm{H}$ value, the result is essentially zero.

The mass balance was finally estimated using the various physical volumes and flows discussed above, and the averages for $\mathrm{Hg}$ and $\mathrm{CH}_{3} \mathrm{Hg}$ for the appropriate regions, as shown on Table 7 . What is striking about the mass flow of $\mathrm{Hg}$ through this system is that it is both quite large, and completely dominated by the resuspension and loss of contaminated sediments from the lagoon. Only about 5\% of the $\mathrm{Hg}$ cycling in the lagoon represents fresh inputs from industrial, urban, and atmospheric sources. This also implies that the standing stock concentrations of $\mathrm{Hg}$ and $\mathrm{CH}_{3} \mathrm{Hg}$ in the lagoon are almost completely supported by exchange with this huge pool of contaminated sediments. From the net flows through the lagoon, we find that it is the source of a rather extraordinary $1110 \mathrm{~kg} \mathrm{year}^{-1}$ into the Adriatic Sea, which would make the Venice Lagoon the second largest known single source of $\mathrm{Hg}$ after the Isonzo River, which flows through the Idria $\mathrm{Hg}$ belt of Slovenia, and deposits approximately $1500 \mathrm{~kg} \mathrm{year}^{-1}$ into the Gulf of Trieste (Sirca et al., 1999). When one considers that all of the $\mathrm{Hg}$ leaving the lagoon is likely to be in the bioavailable organo-complexed fraction (Bloom et al., 2004), while much of the $\mathrm{Hg}$ carried by the Isonzo River is probably in the form of relatively 
Table 7

Simplified mass balances for total mercury $(\mathrm{Hg})$ and monomethyl mercury $\left(\mathrm{CH}_{3} \mathrm{Hg}\right)$ in the Venice Lagoon

\begin{tabular}{|c|c|c|c|c|c|}
\hline \multirow[t]{2}{*}{ Flux Category } & \multicolumn{2}{|c|}{ Mean concentrations used } & \multirow[t]{2}{*}{ Units } & \multicolumn{2}{|c|}{ Mercury flux, $\mathrm{kg}_{\text {year }}{ }^{-1}$} \\
\hline & $\mathrm{Hg}$ & $\mathrm{CH}_{3} \mathrm{Hg}$ & & $\mathrm{Hg}$ & $\mathrm{CH}_{3} \mathrm{Hg}$ \\
\hline Resuspension (north) & 4.66 & 0.0078 & nmol g ${ }^{-1}$ sediments & 1051 & 1.8 \\
\hline Resuspension (south) & 2.20 & 0.0037 & nmol $\mathrm{g}^{-1}$ sediments & 41 & 0.1 \\
\hline Adriatic flux in & 11.0 & 0.065 & $\mathrm{pM}$ water & 308 & 1.9 \\
\hline Industrial inputs & 36.0 & 0.36 & $\mathrm{~kg}$ year $^{-1}$ & 36 & 0.36 \\
\hline River input & 59.0 & 0.960 & pM water & 13.2 & 0.22 \\
\hline Precipitation & 103.5 & 0.410 & pM water & 9.4 & 0.04 \\
\hline Venezia City flux & 424.5 & 1.065 & net $\mathrm{pM}$ water & 11.9 & 0.03 \\
\hline Total inputs & & & & 1471 & 4.5 \\
\hline Adriatic flux out (north) & 74.0 & 0.350 & pM water & 1243 & 5.9 \\
\hline Adriatic flux out (south) & 15.7 & 0.130 & pM water & 175 & 1.5 \\
\hline Mercury evasion & 0.10 & 0.135 & $\mathrm{pM} \mathrm{Hg}$ in water & 4.2 & 0.00 \\
\hline Fish removal & 1.11 & 0.740 & nmol $\mathrm{g}^{-1}$ in fish & 0.43 & 0.29 \\
\hline Total outputs & & & & 1423 & 7.7 \\
\hline Flux to Adriatic & & & & 1110 & 5.5 \\
\hline
\end{tabular}

inert cinnabar particles, we suggest that discharges from the lagoon may be the most significant impactor of the $\mathrm{Hg}$ cycle of the Adriatic Sea. Although the balance for total $\mathrm{Hg}$ is quite good, even in this simplified example we see that about twice as much $\mathrm{CH}_{3} \mathrm{Hg}$ comes out of the lagoon as comes in. This difference represents net production of $\mathrm{CH}_{3} \mathrm{Hg}$ within the lagoon, probably in wetlands and sediments as seen in the Lavaca Bay estuary (Gill et al., 1999). It is likely that there is a much higher flux of $\mathrm{CH}_{3} \mathrm{Hg}$ into the lagoon from these sources, but that it is largely cancelled by photo degradation in this very shallow system (Sellers et al., 1996).

\section{Conclusions}

Although little new $\mathrm{Hg}$ is being added from industrial and urban sources, the Venice Lagoon is highly but diffusely contaminated with $\mathrm{Hg}$ from past industrial discharges. This $\mathrm{Hg}$ has become widely distributed due to intense sediment re-suspension and transport, with approximately $1100 \mathrm{~kg}$ of that historic $\mathrm{Hg}$ carried on suspended matter and discharged to the Adriatic Sea each year. If we assume that the original contamination loading from the two chlor-alkali plants was on the order of $200,000 \mathrm{~kg}$, then it will be centuries before the lagoon completely cleans itself by this mechanism. In addition, loss of sediment is an undesired outcome for the lagoon for other ecological reasons (degradation of wetlands, channel deepening), so that controls to reduce these losses will necessarily retain the $\mathrm{Hg}$. The lagoon is also a considerable source of net methylation, which is flushed out to the Adriatic with each tidal cycle. The degree of this $\mathrm{Hg}$ methylation, particularly as regards production and seepage from wetlands, should be more accurately constrained, so that if projects such as the MOSE tidal gates, shipping channels, or pipelines retard circulation, the consequent build-up of $\mathrm{CH}_{3} \mathrm{Hg}$ in the lagoon can be properly assessed.

Probably the biggest concern for $\mathrm{Hg}$ cycling in the lagoon is the re-suspension of contaminated sediments, and its transport into the more biologically productive salt marsh environments (Bloom and Lasorsa, 1999). To this end, effort should be devoted to modifying human behaviors that serve to mobilize sediments. For example, the northern part of the lagoon experiences near-continuous anthropogenic disturbances to the sediments from a combination of excessive boating speeds, dredging, rebuilding salt marshes, and a type of clam harvesting called la rasca soffiante, where high-powered boats are driven with their propellers submersed in the sediment layer, kicking out the clams into a net towed behind the boat. Although officially illegal, this technique is lucrative and is widely practiced in the less monitored areas of both the northern and southern lagoon (Atti Parlimentari, 2002). Consideration should also be paid 
to replacing the most contaminated tracts of sediments with cleaner material.

Since the loss of sediment from the lagoon is an ecological problem in its own right, another consideration might be to re-divert fresh water back to the lagoon, bringing new loading of cleaner sediments that might ultimately bury or dilute the current high concentrations. Such a move would have to be considered carefully, however, since an unintended consequence might be an increase in methylation rates, as sulfate levels are diluted to those more optimal for maximum methylation (Gilmour et al., 1992). A further area of potential importance to the $\mathrm{Hg}$ cycle of the lagoon is the role played by the extensive network of diked fish farms, which, because of high rates of feeding and excretion, could be areas of high microbial activity and so methylation. The degree to which inorganic $\mathrm{Hg}$ contamination has reached these areas, as well as the amount of water exchange with the main body of the lagoon, will play major roles as well.

The estimates of substantial fluxes of $\mathrm{Hg}$ and $\mathrm{CH}_{3} \mathrm{Hg}$ cycling within the lagoon and transported to the Adriatic should encourage further studies to extend the results of the present investigation, which focus primarily on the northern half of the lagoon. Greater detail is needed for the southern lagoon, and on the temporal and spatial distributions of $\mathrm{Hg}$ in rain, biota, and sediments. Extensive work is also necessary to obtain fluxes from potentially high-methylating areas such as natural and reconstructed wetlands and diked fish farms.

\section{Acknowledgments}

The authors would like to thank the Universita Ca'Foscari di Venezia Murst/MIUR (Rome), project 28 Cluster 22, for their funding of various projects brought together in this paper including samples donated to the authors by Dr. A. Franco, Prof. Sfriso, and Cinzia Bettiol. In addition, we would like to pay special thanks to Italo Ongaro for the use of his boat and his guidance in finding sample sites. Additional thanks are due to Marie Antonietta Baldo, Crystal Howard, Martina Tassone and Isaac Goldblatt-Bloom for their invaluable assistance in the collection of field samples, and to Eric von der Geest for providing $\mathrm{Hg}$ analyses. Finally, we thank Sharon Goldblatt and Beverly van Buuren for their expert editorial assistance in rendering the manuscript suitable for publication.

Associate editor: Dr. Peter J. Statham.

\section{References}

Atti Parlimentari 2002 Camera dei deputati, allegato B ai resoconti, 6 Marzo 2002. http://www.camera.it/_dati/leg14/Lavori/stenografia/ sed110/pdfbt36.pdf.

Bernstein, A.G., Cecconi, G., 1995. The impact of the Venice tidal barriers on water quality. Consorzio Venezia Vuova, Venice, Italy, pp. 89-95.

Bloom, N.S., 1992. On the chemical speciation of mercury in edible fish muscle tissue. Can. J. Fish Aquat. Sci. 49, 1010.

Bloom, N.S., 1995. Mercury as a case study of ultra-clean sample handling and storage in aquatic trace metal research. Environ. Lab., 20-26 (March/April).

Bloom, N.S., Crecelius, E.A., 1983. Determination of mercury in seawater at sub-nanogram per liter levels. Mar. Chem. 14, 49-59.

Bloom, N.S., Fitzgerald, W.F., 1988. Determination of volatile mercury species at the picogram level by low temperature gas chromatography with cold vapor atomic fluorescence detection. Anal. Chim. Acta 208, 151-161.

Bloom, N.S., Lasorsa, B., 1999. Changes in mercury speciation and the release of methyl mercury as a result of marine sediment dredging activities. Sci. Total Environ. 237/238, 285-379.

Bloom, N.S., von der Geest, E.J., 1995. Matrix modification to improve recovery of $\mathrm{MMHg}$ from clear waters using the acid/chloride distillation procedure. Water Air Soil Pollut. 80, 1319.

Bloom, N.S., Watras, C.J., Hurley, J.P., 1991. Impact of acidification on the methylmercury cycle of remote seepage lakes. Water Air Soil Pollut. 56, 477.

Bloom, N.S., Prestbo, E.M., Kuhn, E.S., Tokos, J.J.S., von der Geest, E.J., 1995. Distribution of mercury species in the Pacific Northwest atmosphere. Am. Chem. Soc. Annual Meeting, Chicago, IL. Abstract.

Bloom, N.S., Coleman, J.A., Barber, L., 1997. Artifact formation of methyl mercury during extraction of environmental samples by distillation. Fres. Anal. Chem. 358, 371-377.

Bloom, N.S., Gill, G.A., Cappellino, S., Dobbs, C., McShea, L., Driscoll, C., Mason, R., Rudd, J.W.M., 1999. Speciation and cycling of mercury in Lavaca Bay, Texas sediments. Environ. Sci. Technol. 33, 7-13.

Bloom, N.S., Preus, E.M., Katon, J., Hiltner, M., 2003. Selective extractions to assess the biogeochemically relevant fractionation of inorganic mercury in sediments and soils. Anal. Chim. Acta 479, 233-248.

Bloom, N.S., Moretto, L.M., Ugo, P., 2004. A Comparison of the speciation and fate of mercury in two coastal marine ecosystems: the Venice Lagoon (Italy) and Lavaca Bay (Texas). Limnol. Oceanogr. V49, 367-375.

Canu, D.M., Umgeisser, G., Solidoro, C., 2001. Short-term simulations under winter conditions in the Lagoon of Venice: a contribution to the environmental impact assessment of temporary enclosure of the inlets. Ecol. Model. 138, 215-230. 
Conaway, C.H., Squire, S., Mason, R.P., Flegal, A.R., 2003. Mercury speciation in the San Francisco Bay estuary. Mar. Chem. 80 (209), 199-225.

Critto, A., Marcomini, A., 2001. Rischio ecologico e inquinamento chimico lagunare. Liberia Editrice Cafoscarina, Venezia, Italy.

Day, J.W., Are, D., Rismondo, A., Scarton, F., Cecconi, G., 1995. Relative sea level rise and Venice Lagoon wetlands. Consorzio Venezia Vuova, Venice, Italy, pp. 24-34.

Gill, G.A., Bloom, N.S., Dobbs, C., Driscoll, C.T., Mason, R.M., Rudd, J.W.M., 1999. Sediment-water fluxes of mercury in Lavaca Bay, TX. Environ. Sci. Technol. 33, 663-669.

Gilmour, C.C., Henry, E.A., Mitchell, R., 1992. Sulfate stimulation of mercury methylation in freshwater sediments. Environ. Sci. Technol. 26, 2281-2287.

Giordano, R., Arata, P., Ciaralli, L., Rinaldi, S., Giani, M., Cicero, A.M., Costantini, S., 1991. Heavy metals in mussels and fish from Italian coastal waters. Mar. Pollut. Bull. 22, 10-14.

Granzotto, A., Franzoi, P., Longo, A., Pranovi, F., Torrecelli, P., 2001. La pesca nella la laguna di Venezia: un percorso di sostenibilità nel recupero delle tradizioni. Lo stato dell'Arte. Rapporto sullo sviluppo sostenibile. Fondazione Eni Enrico Mattei, Milano, Italy.

Horvat, M., Bloom, N.S., Liang, L., 1993. A comparison of distillation with other current isolation methods for the determination of methyl mercury compounds in low level environmental samples, part 2, water. Anal. Chim. Acta 282, 153.

Horvat, M., Kotnki, J., Fajon, V., Logar, M., Zvon der Geestaric, T., Pirrone, N., 2001. Speciation of mercury in waters of the Mediterranean Sea. RMZ-Mater. Geoenviron. 48, 241-252.

Hurley, J.P., Benoit, J.M., Babiarz, C.L., Shafer, M.M., Andren, A.W., Sullivan, J.R., Hammond, R.H., Webb, D.A., 1995. Influences of watershed characteristics on mercury levels in Wisconsin rivers. Environ. Sci. Technol. 29, 1867-1875.

Leermakers, M., Meuleman, C., Baeyens, W., 1995. Merucyr speciation in the Scheldt estuary. Water Air Soil Pollut. 80, $641-652$.

Locarnini, S.J.P., Presley, B.J., 1996. Mercury concentrations in benthic organisms from a contaminated estuary. Mar. Environ. Res. 41, 225-239.

Marcomini, A., Sfriso, A., Pavoni, B., Orio, A.A., 1995. Eutrophication of the Lagoon of Venice: nutrient loads and exchanges. In: McComb, A.J. (Ed.), Eutrophic Shallow Estuaries and Lagoons. CRC Press, Boca Raton, Florida, USA, pp. 59-80.

Moretto, L.M., Bloom, N.S., Scopece, P., Ugo, P., 2003. Application of ultra-clean sampling and analysis methods for the speciation of mercury in the Venice Lagoon (Italy). J. Phys. IV France 107, 887-890.

Pavoni, B., Sfriso, A., Donazzolo, R., Orio, A.A., 1990. Influence of waste waters from the city of Venice and the hinterlands on the eutophication of the lagoon. Sci. Total Environ. 96, 235-252.

Pellizzato, M., 1996. Pesca e Acquocultura. La Laguna di Venezia un Patrimonio de Scoprire. Filippi Editori, Venezia.

Sellers, P., Kelly, C.A., Rudd, J.W.M., MacHutchon, A.R., 1996. Photodegradation of methylmercury in lakes. Nature 380, 694-697.

Sirca, A., Horvat, M., Rajar, R., Covelli, S., Zagar, D., Faganeli, J., 1999. Estimation of mercury mass balance in the Gulf of Trieste. Acta Adriat. 40, 75-85.

Turner, R.R., Southworth, G.R., 1999. Mercury-contaminated industrial and mining sites in North America: an overview with selected case studies. In: Ebinhaus, R., Turner, R.R., de Lacerda, L.D., Vasiliev, O., Solomons, W. (Eds.), Mercury Contaminated Sites. Springer, Berlin, pp. 89-112.

Ugo, P., Zampieri, S., Moretto, L.M., Paoluccia, D., 2001. Determination of mercury in process and lagoon waters by inductively coupled plasma-mass spectrometric analysis after lectrochemical preconcentration: comparison with anodic stripping at gold and polymer coated electrodes. Anal. Chim. Acta 434, 291-300.

Vandal, G.M., Mason, R.P., Fitzgerald, W.M., 1991. Cycling of volatile mercury in temperate lakes. Water Air Soil Pollut. 56, $791-803$.

Vermette, S., Lindberg, S., Bloom, N.S., 1995. Field tests for a regional mercury deposition network-sampling design and preliminary test results. Atmos. Environ. 29, 11.

Watras, C.J., Bloom, N.S., 1992. Mercury and methylmercury in individual zooplankton: implications for bioaccumulation. Limnol. Oceanogr. 37, 1313.

Zaggia, J., Zuliani, A., Zonta, R., 2001. Analysis of rainfall data. DRAIN Project Workshop: Discussion and Presentation of the Methods and Main Results of the DRAIN Project. Consorzio Venezia Vuova, Venice, Italy, pp. 37-44.

Zuliani, A., Zonta, R., Zaggia, L., Fagarazzi, O.E., 2001. Fresh water transfer from the drainage basin to the Venice Lagoon. DRAIN Project Workshop: Discussion and Presentation of the Methods and Main Results of the DRAIN Project. Consorzio Venezia Vuova, Venice, Italy, pp. 31-36. 